International Journal of Linguistics, Literature and Translation

ISSN: 2617-0299 (Online); ISSN: 2708-0099 (Print)

DOI: $10.32996 / \mathrm{ijllt}$

Journal Homepage: www.al-kindipublisher.com/index.php/ijltt

IJLLT

\title{
Discussion Analysis Based on the Symlog Model: A System for the Multiple Level Observation of Groups
}

\author{
Nuramila, S.Pd., M.Pd \\ Makassar State University Postgraduate Alumni, Indonesia
}

$\square$ Corresponding Author: Nuramila, S.Pd., M.Pd, E-mail: nuramila01@gmail.com

\begin{abstract}
ARTICLE INFORMATION
Received: 15 October 2021

Accepted: 10 November 2021

Published: 30 November 2021

DOI: $10.32996 /$ ijllt.2021.4.11.22
\end{abstract}

\section{KEYWORDS}

Terrorism, SYMLOG, discourse analysis

\section{ABSTRACT}

News about acts of terrorism has colored many media. Terrorism has been identified with taboo activities in actions that often threaten the peace and tranquility of the community, which always threaten and cause many casualties. One of the media that reports on terrorism are the online news portal Republika.co.id. Of the many reports that exist, the researcher tries to examine how the media, especially online portals, report the reality of terrorism events using the SYMLOG (method of discourse analysis A System for the Multiple Level Observation of Groups). Critical discourse is a series of knowledge and beliefs that are constructed by certain communities in discourse (in this case terrorism discourse) with the hope that their goals can be achieved. Behind the choice of words, phrases, clauses, sentences, paragraphs, and texts hidden ideology and power. Based on this background, the problems in this research are formulated, namely: (1) How is the construction of terrorism discourse using the SYMLOG model in thenews media Republika.co.id? (2) How is the linguistic representation in the discourse of terrorism in thenews media Republika.co.id?. The approach used in this study is a qualitative approach. Then the type of research used in this research is descriptive research. The primary data in this study is the entire research subject studied. In this case, the researcher took 10 news stories on Republika.co.id related to terrorism. The researcher acts as the main instrument in this research. The data collection technique used in this research is to use documentation, listening techniques, and recording. Based on the results of the study, it was found that the construction of the SYMLOG model of terrorism discourse in thenews media Republika.co.id used the form of verbal behavior, pro values, contra values, setbacks, conflicts, sympathy, achievements. Linguistic representations in the discourse of terrorism in thenews media Republika.co.id are at the level of verbs, clauses, sentences, adjective phrases, verb phrases, noun words, and noun phrases.

\section{Introduction}

Terrorism is a global threat that requires global action and collaboration to deal with it. News of acts of terrorism has colored many mass media, both print and electronic media, for a few moments or even weeks since the Sarinah Bombing explosion in the Jalan $\mathrm{MH}$ area. Tamrin Jakarta. Terrorism is coordinated attacks aimed at evoking feelings of terror against a group of people. In contrast to war, acts of terrorism are not subject to war procedures, such as the execution time which is always sudden and the target of casualties is random and often civilians.

Bombings or acts of terrorism have a long history in Indonesia. In the period from 2000 to 2009 bombings have occurred repeatedly in Indonesia. Bombing events that occur in Indonesia are referred to as terror events and are identified with terrorist activities. Terror and terrorism go hand in hand and narrow to the mention of certain activities that are classified as acts of terrorism.

Copyright: (c) 2021 the Author(s). This article is an open access article distributed under the terms and conditions of the Creative Commons Attribution (CC-BY) 4.0 license (https://creativecommons.org/licenses/by/4.0/). Published by Al-Kindi Centre for Research and Development, London, United Kingdom. 
From the news presented by the mass media, both print media, and electronic media, terrorism has been identified with taboo activities in actions that often threaten the peace and tranquillity of the community, which always threaten and cause many casualties. In addition, many classifications of terrorist leadership paths have been identified by the Indonesian National Police.

One of the mass media reporting on terrorism is the online news portal Republika.co.id. Various news contents are always raised by the media related to the terrorist acts, starting from the chronology of events, victims of the bombing, the actions of the perpetrators, preventive actions and actions of resistance, and the conditions and responses of the community. Many people are also worried about the acts of violence carried out by this action.

With the high intensity of reporting about this act of terrorism, the action has become increasingly public attention. Of the many reports, the researcher tries to examine how the media, especially the mass media (online portals) report on the reality of terrorist acts. By using discourse analysis method SYMLOG (A System for the Multiple Level Observation of Groups).

Critical discourse is a series of knowledge and beliefs that are constructed by certain communities in discourse (in this case, terrorism discourse) with the hope that their goals can be achieved, behind the choice of words, phrases, clauses, sentences, paragraphs, and texts hidden ideology and power.

In this discourse analysis, the SYMLOG (the method is used System for the Multiple Level Observation of Groups). This method is based on social cognition theory, symbolic interactionism, social exchange theory, and the family therapy approach. This method is called multilevel because it considers group dynamics and individual personalities and provides systematic insight into the relationship between individual dynamics and social group dynamics.

Every journalist's view of reporting on this act of terrorism will always have a different point of view. In the constructionist paradigm, the media is not only a channel for information messages, but the media can act as an agent for generating an information message. Reports of acts of terrorism that often appear in the media attract people's attention because they are always colored by violations in the form of various acts of murder, explosions, attacks that cause fear of suffering by hurting a person or group to exceed the limits of social values.

The visions and policies contained in every media cause the press to accept the fact that there is no objectivity absolute in their work, even though the press tries to be objective in covering and selecting an event, but with the vision and editorial policies issued, it can influence the news presented. As a result, readers will find events written in different ways and analyzed.

The news portal was Republika.co.id chosen as the object of this research because the portal always presents the most updated news in a short and continuous time. In addition, in the context of reporting on terrorism, Republika.co.id presents more complete, clearer, and more informative news than other online media.

News as a product of journalism can produce a reality that is different from the condition of the object that occurs in the field. Therefore, according to Nugroho, media studies are known as existence, actual reality, and media reality. The Entman concept broadly describes how journalists interpret and mark events differently by the mass media. The meaning and understanding can be marked from the use of labels, words, sentences, graphics, and certain emphasis in the news narrative. The selected news texts will be analyzed using the SYMLOG method model.

Based on the description above, the researchers are interested in conducting research: "Terrorism Discourse Based on the SYMLOG Model (A System for the Multiple Level Observation of Groups): Critical Study".

Based on this background, the research problems are formulated: (1) How is the construction of terrorism discourse using the SYMLOG model in thenews media Republika.co.id? (2) How is the linguistic representation in the discourse of terrorism in thenews media Republika.co.id?

\section{Literature Review}

\subsection{Mass}

Media is a tool or means used to convey messages from communicators to audiences.

\subsection{Online}

News News is new information or information about something that is happening, presented through print, broadcast, Internet, or word of mouth to a third person or crowd. Media can be interpreted as a channel or tool, while online is a language term on the internet, meaning information that can be accessed anywhere as long as there is an internet network. According to the book Applied Journalism written by Syarifudin Yunus (2010: 27), online media, namely internet media, such as websites, blogs, and others published/aired in cyberspace, can be read and viewed on the internet. Media online is a new player in the Indonesian press scene. According to several sources, online media in Indonesia has grown since 1994. 


\subsection{Terrorism}

According to the Big Indonesian Dictionary (KBBI), terrorism means the use of violence to create fear in an effort to achieve goals (especially political goals); acts of terror. Terrorism is an action based on a value system and worldview, so understanding it requires a framework and methodology of thought commonly used in the philosophical tradition. In its development, a concept emerged that understood that terrorism is a method or technique of intimidation with a systematic target for the sake of a certain political interest. (Hendropriyono, 2009: 25).

The goals of the perpetrators of terrorism and their motivations in the past varied, namely for economic gain (gold), gaining social prestige (glory), imposing ideology, interpretation of beliefs or exploitation of religion, culture, hegemony, power, cultural domination, or coercion of philosophical concepts. (Hendropriyono, 2009: 37)

\subsection{Critical Discourse Analysis of the SYMLOG Model (A System for the Multiple Level Observation of Groups) by Bales \& Cohen}

SYMLOG is an acronym for System for the Multiple Level Observation of Group. This method is based on social cognition theory, symbolic interactionism, social exchange theory, and the family therapy approach. This method is called multilevel because it considers group dynamics and individual personalities and provides systematic insight into the relationship between individual dynamics and social group dynamics.

The SYMLOG method has the aim of studying social groups and how they relate to those groups. In this method, each group must (a) integrate its members emotionally, (b) resolve tensions that arise, (c) make decisions. The SYMLOG method procedure combines behavior, content, and values in the form of messages that function to record interaction time, interaction actors, language comments about interaction behavior, values expressed by actors interacting with ideas.

\section{Research Methodology}

The qualitative descriptive approach was used in this study. This study seeks to understand the meaning of discourse events that occur in terms of terrorism. The data collected was in the form of written words. The research was conducted to provide a comprehensive and in-depth description of the phenomenon of terrorism. The final result of the study provides an explanation of the taxonomy, theoretical basis, and language education under study.

Research subjects are various sources of information obtained as research data. The subject of this research is in the form of documents, namely news texts at www.republika.co.id. The primary data in this study is the entire research subject studied. In this case, the researcher took 10 news stories at www.republika.co.id associated with terrorism.

Researchers act as the main instrument in this study (Bogdan \& Bilken, 1982). Apart from being a data processor and interpreter, the researcher functions as a data collection tool.

The data collection technique used in this research was based on documentation, listening techniques, and recording. Data analysis was made in terms of data identification, data reduction, data presentation, and conclusions.

\section{Results and Discussion}

\subsection{Verbal Behavior Verbal}

the behavior occurs in the form of communication in the context of conveying one's thoughts, messages, or feelings to others by using symbols that use one or more words as a medium. The media that is often used is language because language can translate one's thoughts to others.

\subsection{Verbs}

Verbs are defined as a class of words that express an action or deed. An action or action related to "state", "say", "read", "chat", "say", "talk", "say", "mention". In the discourse of terrorism, it is found that these verbs have or are ideologically verbal behaviors. Data related to the discussion is presented as follows:

(1) Meanwhile, Coordinating Minister for Political, Legal, and Security Affairs General TNI (ret) Wiranto stated that hoaxes in cyberspace are a real threat in his speech. (News 1)

Based on data (1), it is interpreted that there is a statement from the Coordinating Minister for Political, Legal and Security Affairs General TNI (Ret.) Wiranto that news hoax in cyberspace is a serious threat. This is considered a threat because the existence of news hoaxes or fake news can cause fear from the public, panic, and so on. This public confusion can be used by irresponsible parties to instill hatred so that there is a chance for division and hostility, especially what often occurs in relation to radicalism is inter-religious hostility. In the SYMLOG method, the verb "to state" is categorized as a form of verbal behavior. This means that behavior in which communication involves language, in this case, is in the form of spoken language spoken by the Coordinating Minister for Political, Legal, and Security Affairs General TNI (Ret.) Wiranto. So the verbal behavior, in this case, is marked by the 
verb "declare". The speech delivered was "There is a change in the dynamics of threats that continue to change from time to time. One dynamic movement and if we get carried away, we will easily fall behind."

\subsection{Clause A}

A clause is a syntactic unit in the form of a series of words with predicative construction. In the construction, there are components, in the form of words or phrases, which function as predicates; and the other functions as a subject, object, and adverb. In the discourse of terrorism, there are clauses that have or are syntactic units in the form of a series of words with predicative construction. Data language relating to it are presented as follows:

(17) For example, in a family there are children who begin bandwagon and acting strange, to be invited to speak or be invited to dialogue by parents or scholars in their environment,

In the data (17), researchers interpret that the way to protect children who start to go along and behave strangely and seem to have started to be indoctrinated by the notion of terrorism is through communication. In general, communication between parents and children is very important when dealing with terrorist attacks. Families will be better prepared to deal with terrorist attacks if they have discussed scenarios before, during, and after the incident so that everyone can relieve their worries and fears. The clause "to talk to" in data 17 is a form of verbal behavior because, in its implementation, it involves words, namely, in this case, verbally speaking to children so that children can express their feelings.

\subsection{Values Pro}

Pro means really good, positive, or to agree with something. This analysis is marked by the existence of a linguistic level which means being pro to something that is in the news of terrorism in Republika.co.id.

\subsubsection{Sentence}

A sentence is a combination of two or more words that produce an understanding and final intonation pattern. The linguistic data related to this is presented as follows:

(19) In essence, Arief agrees that the parties who make efforts to divide this will be dealt with firmly.

In data (19), the researcher interprets that Arief's side as a member of the Indonesian House of Representatives from the Hanura Faction is to take firm action against parties who make efforts to divide because these actions cause riots and violence that injure national principles. This action must be implemented so as not to disturb the security and brotherhood that has been built in the community. The sentence "Essentially, Arief agrees that those who attempt this division will be dealt with firmly" is a linguistic construction that contains pro values. This is indicated by "Arief agrees".

\subsubsection{Adjective}

An adjective phrase is a group of words (two or more words) with an adjective as the core. The core element in the phrase is the element that is explained by another element: an element of pewatas (which explains). However, according to the definition of an adjective, the adjective phrase is still the part that explains the noun. The linguistic data related to this is presented as follows:

(22) This effort absolutely must be made because the virtual world, be it the internet and social media, is the vehicle most effective for conducting campaigns.

In the data (22) the researcher interprets that there is a Pro value for the efforts made. In this case, the effort referred to is the dissemination of information and writings about Islam that is rahmatan lil alamin in the language and ways of young people. The sentence "This effort absolutely must be done because the virtual world, be it the internet and social media, is the most effective vehicle for conducting campaigns" contains a pro value which lies in "most effective".

\subsection{Contra Value}

A counter value is a value that contains a state of disagreement, opposition related to opinions.

\subsubsection{Verb Phrases}

Phrases in the linguistic perspective are defined as one-parent endocentric phrases whose main verb is a verb and part of a sentence that functions as a predicate. Verbs related to terrorism are "can poison", "can contaminate". The linguistic data related to this is presented as follows:

(23) News Hoax and radicalism that is spread through irresponsible media and social media can poison people and contaminate a person's soul. 
In the data (23), the researcher interprets a counter value aimed at social media that presents news hoaxes and spreads radicalism because it can contaminate a person's soul. The verb phrase "can poison" is a form of the counter value. This phrase has a connotative meaning that implies that news hoaxes and radicalism can influence the perspective of many people. Smart, radical groups take advantage of cyberspace by turning the situation around to look like it's true and hoping for a profit. This is something that users of the virtual world must watch out for so that they are not affected or poisoned by the fake news.

\subsubsection{Adjective}

An adjective phrase is a group of words (two or more words) with an adjective as the core. The core element in the phrase is the element that is explained by another element: an element of pewatas (which explains). However, according to the definition of an adjective, the adjective phrase is still the part that explains the noun. The linguistic data related to this is presented as follows:

(26) According to the former Chancellor of UIN Syarif Hidayatullah Jakarta, radical terrorist groups tend to be intolerant and easily condemn others who do not share their views.

In the data (26) the researcher interprets that radical groups do not tolerate people who are not like-minded. This is a counter value. Radical groups carry out the counter value here. They have a contra view of people who do not share with them. They are intolerant of freedom of religion and belief, so that they carry out acts of terror, intimidating certain beliefs that are considered inappropriate or deviant. The adjective phrase "tends to be intolerant" shows a counter value, namely that terrorism groups are not pro against people who have different beliefs from them.

\subsection{Reward}

The meaning of setback in this case is a matter of retreat in terms of social life. In other words, social change is a mismatch of the different elements that exist in society so as to produce a pattern of life whose functions are not in harmony. The situation is worse than before.

\subsubsection{Noun}

Nouns from a linguistic perspective are categorized as word classes. Nouns or nouns are words that refer to people, things, and concepts or meanings. In terms of syntax, nouns have the following characteristics: In sentences where the predicate is a verb (verb), nouns tend to occupy the function of the subject, object, or complement. The linguistic data related to this is presented as follows:

(28) A dynamic movement and if we are carried away we will easily fall behind.

In data (28) the researcher interprets a setback. Setback in this case means lagging behind as in the noun "lost" to the changing dynamics of the threat. The threat in question is a threat to the spread of news hoaxes in cyberspace. This lag will occur if the police and the community are not alert to fight and be aware of the threats of the influence of radicalism where terrorists are currently aggressively carrying out various ways, including currently through cyberspace to be able to find and recruit new terrorist candidates to can join and have an understanding that is in line with the group.

\subsubsection{Adjective Phrases}

In linguistics, an adjective phrase is a group of words (consisting of two or more words) with an adjective as the core. However, according to the definition of an adjective, the adjective phrase is still the part that explains the noun. The linguistic data related to this is presented as follows:

\section{(29) "I just said that this nation has lost a lot.}

In data (29) the researcher interprets that the setback in question is contained in the adjective phrase "very loss". This is addressed to the Indonesian people who want to destroy Pancasila. Make the phenomenon of the election of Regional Heads (Pilkada) a place to divide the nation by using religious issues. Not only done through social media but to use pamphlets that are distributed to the public. This can provide doctrine to the community so that it divides the nation and integrity of the Republic. It is a setback. Hence the phrase "lose all " is included in the category of a setback. With the terrorism manggambarkan man suffered setbacks primarily moral and humanism.

\subsubsection{Sentence}

A sentence is a unit of speech smallest, in the form of oral or written, that reveals the mind whole. A sentence is a combination of two or more words that produce an understanding and final intonation pattern. The linguistic data related to this is presented as follows: So 
(30) far, law enforcement officials have not been able to take action against groups conducting military training that are known to commit acts of terrorism.

In the data (30), the researcher interprets the existence of a setback experienced by law enforcement in this case the police. This is because the police cannot take action against terrorist groups due to the absence of a strong and comprehensive terrorism law so that the perpetrators cannot be prosecuted. Revision of the previous law is needed, namely Law No. 15 of 2003 concerning eradicating acts of terrorism. It should also be regulated regarding criminal activities for military training carried out by terrorist groups and related to recruiting members and incitement. The sentence signifies a marked decline from "can't".

\subsection{Conflict}

Conflict is related to squabbles, disputes, or contradictions.

\subsubsection{Noun Words}

Basically, nouns from a linguistic perspective are categorized as word classes. The noun class found in terrorism news relates to "war", "violence". The linguistic data related to this is presented as follows:

(31) Due to war in cyberspace, such as social media, various propaganda information is used.

In the data (31) the researcher interprets the existence of a problem that occurs. The problem is related to the spread of news hoaxes that can incite and become propaganda so that it also spreads hatred and causes division. The noun "war" in this case is not physical but rather idealism or understanding. The war was fought by terrorist groups who tried to carry out propaganda through cyberspace so that someone would enter and agree with their ideals.

\subsubsection{Clause $A$}

A clause is a level in syntax that is above the phrase level and below the sentence level. A clause is a syntactic unit in the form of a series of words with predicative construction. In the construction, there are components, in the form of words or phrases, which function as predicates; and the other functions as a subject, object, and adverb. In the discourse of terrorism, some clauses have or are syntactic units in the form of a series of words with predicative construction. The linguistic data related to this is presented as follows:

(33) "Some terrorists are the result of propaganda in cyberspace. They also carry out terror with independent methods, or called lone wolves,"

In data (33), researchers interpret a conflict that causes people to experience conflict-psychological damage such as fear, trauma, paranoia, and even other mental disorders. In fact, society is always haunted by fears of the form of terrorism, which causes psychological effects for young Indonesians who are still emotionally unstable. All these negative influences directly disrupt the life of the nation and state. Not to mention the existence of groups that want to change the nation's ideology. In addition, this terror can also kill other people's lives and property or cause damage or destruction to vital strategic objects or the environment or facilities.

\subsubsection{Noun Phrases}

In linguistics, a noun phrase is a group of nouns formed by expanding a noun. The discussion data related to this is presented as follows:

(36) This year there were at least three acts of a lone wolf, namely the attack priest on aat, a church in Medan, the suicide bombing at the Solo Police Headquarters, and the attack on police officers in Tangerang.

In the data (36) the researcher interprets the conflict that is displayed through the noun phrase "assault of the priest". The terrorist group carried out the conflict to the priest. This is also a form of counter-terrorist groups to other people who disagree with them.

\subsection{Sympathy}

Sympathy in this case means compassion; agreement; a sense of liking or participation to feel the feelings (happy, difficult, etc.) of others. 


\subsubsection{Sentence}

A sentence is a combination of two or more words that produce an understanding and final intonation pattern. The linguistic data related to this is presented as follows:

(38) Responding to this, Hendri gave high appreciation for the efforts of the National Counterterrorism Agency (BNPT) in printing peace ambassadors in cyberspace.

In data (38) the researcher interprets a sympathy that comes from Hendri as a Political Communication Expert from Paramadina University to BNPT. The sentence "Hendri gives high appreciation" is a form of sympathy or love for the BNPT's performance in printing peace ambassadors in cyberspace. This peace ambassador aims to train the younger generation so that they can campaign or carry out peaceful actions in cyberspace, considering the large number of cyber users who are the younger generation.

\subsection{Achievements}

Achievement is the result that has been achieved from what has been done.

\subsubsection{Adjective}

Phrases An adjective phrase is a group of words (two or more words) with an adjective as the core. The core element in the phrase is the element that is explained by another element: an element of pewatas (which explains). However, according to the definition of an adjective, the adjective phrase is still the part that explains the noun. The linguistic data related to this is presented as follows:

(39) Although Indonesia is known as a country that is quite successful in fighting terrorism, Indonesia still needs the assistance of intelligence information from other countries. There is a need for cooperation between countries to exchange data related to terrorist networks and perpetrators.

In the data (39), the researcher interprets the power of the adjective phrase "quite successful". This is a form of achievement. The security forces prove that the terrorists continue to be arrested. On the other hand, the terrorist network has begun to narrow and split.

\subsubsection{Sentence}

The sentence is a combination of two or more words that produce an understanding and final intonation pattern. The linguistic data related to this is presented as follows:

(40) According to him, the government has acted quickly to provide a kind of campaign either through social media or other media to urge the public to be more selective and check and check to stem hoaxes.

In data (40), the researcher interprets that a form of achievement achieved by the government is a quick action in campaigning to the public regarding news that should not be taken for granted, given the spread of news hoax that is increasingly widespread. Campaign means in the form of education given to the public so that they are selective in receiving news so that they are not easily propagated in the teachings of terrorism.

\section{Conclusion}

The current study tried to examine how the media, especially online portals, report the reality of terrorism events using the SYMLOG (method of discourse analysis A System for the Multiple Level Observation of Groups). Based on the study results, it was found that the construction of the SYMLOG model discourse in the news media Republika.co.id used the form of verbal behavior, pro values, contra values, setbacks, conflicts, sympathy, achievements. Linguistic representations in the discourse in the media, namely Republika.co.id news, are at the level of verbs, clauses, sentences, adjective phrases, verb phrases, noun words, and noun phrases.

\section{References}

[1] Cangara, H. (2008). Ilmu Komunikasi Pengantar Studi. Jakarta: Rajawali Pers.

[2] Eriyanto. (2001). Analisis wacana: pengantar analisis teks media. LKiS Yogyakarta.

[3] Jufri. (2008). Analisis Wacana Kritis. Makassar: Badan Penerbit UNM.

[4] Nurudin, N. (2007). Pengantar Komunikasi Massa. RajaGrafindo Persada.

[5] Titscher, S. (2009). Metode Analisis Teks \& Wacana. Yogyakarta: Student Library. 